\title{
Towards Operationalizing Complex Development Approaches
}

\author{
By Winfried Manig*
}

\section{Problem Setting}

An analysis of the development process in the last decades shows that most of the expectations could not be met. One important reason for the unsatisfactory success and, often, for the expansion of social polarization and absolute poverty is likely to be the theoretical approaches on which development policy is based. The commonly applied one-dimensional development approaches did not succeed in delineating the consequences of interfering with the complex system of interdependent social and physical relationships and, therefore, do not supply an appropriate operational pattern.

If it is assumed that development, in its broad sense, means improving the living conditions of all people in the 'Third World countries, it is necessary that changes be effected in society as a whole with a view to achieving this ultimate objective. But this also means that the interdependences of specific social fractions should be taken into consideration in the process of development and thus undesired side effects could be avoided. Therefore, the concepts which are appropriate for intervening in the process and for evaluating the consequences of interventions are only complex, well-balanced development approaches per se.

Since the majority of the population in most of the developing countries lives in the rural areas, and migration to urban centres is not considered to be desirable for political, economic, and social reasons, the development of these regions is a necessity dictated by the conditions. For influencing rural development, similarly to the above-mentioned argument, only multi-dimensional and multi-sectoral complex rural development concepts are appropriate which, in turn, are sub-systems of approaches affecting the whole society. Since a few years, such a complex concept for rural regions has been under discussion as "Integrated Rural Development Approach" (IRD). Although all the aspects and consequences of this approach are not yet evident and undisputed, it basically involves all the relevant segments of societies in which changes should be effected in a complex system.

However necessary such an extensive development concept is, on the one hand, it is not possible to use it directly and immediately as an operational guideline for practical

* The author is indebted to Frithjof Kuhnen und Hartwig de Haen for helpful comments on an earlier draft.

1 See also the criticism in (46, pp. $6 \mathrm{ff}$.). The interdependence of the various social sectors which are sometimes considered in their change as preconditions for developing other fields such as agrarian reforms ought not to be used as a pretext and excuse for inactivities $(8$, pp. $3 \mathrm{ff}$.). 
development policy. ${ }^{1}$ Since all activities are subject to spatial and temporal limitations (which also depend upon the resources), that is, everything cannot be changed everywhere at the same time if influence is exercised, there are two (!) possibilities of solving the problem if the complex approach is adhered to:

- on the one hand, the comprehensive concept can be used as a framework for assessing the consequence of single approaches.

- on the other hand, it is possible to disaggregate the complex approaches (here, the IRD) into individual strategical sectors and to make them operational while largely adhering to the overall concept.

In this contribution, the second possibility will be examined in a few sectors considered to be essential and which, at the same time, have strategical functions for others. On the one hand, the elaboration of a settlement pattern which is appropriate for development in the rural areas in developing countries is considered to be of equal importance. On the other hand, adjusted sectoral, spatial, and temporal investment patterns are likely to be important under the strategical aspect. but only a combination of both allows decision patterns referring to space and time in the terms mentioned above. To that end, Nurske's strategy of rbalanced growth (39) and Christaller's central place theory (9) are integrated in their relevant elements. ${ }^{2}$

In the following, a few aspects of the IRD-concept will therefore be dealt with briefly, and important problematical elements resulting from a combination of the two approaches within the framework of rural development then discussed. Indeed, it is obvious that, in its scope, the combined approach discussed here transcends the concepts of rural development.

\section{The Integrated Rural Development Concept}

As yet, the IRD concept is not a closed set of statements on fields in which changes are effected and their relations. ${ }^{3}$ There are serious differences regarding definitions, divergences as to the implications of the concept, and, especially, the consequences at the operational level in practical development policy. Despite these problematical aspects, a few important components of the concept can be postulated. The approach basically assumes the recognition of a complex system in the development process into which all fractions of the society are integrated. In that respect, the concept should be seen as a goal for integrating marginal groups into the overall society ${ }^{4}$ since development can only take place if all the groups are integrated. On the other hand, the IRD concept is also a methodological approach (26, pp. $137 \mathrm{ff}$.) towards an integral change by exercising

2 It is assumed that the two approaches, even in their elaboration by other authors, are known in their main parts.

3 Here, reference can only be made to the abundant literature. See, for example $23 ; 26 ; 28 ; 47 ; 56$ ).

4 See especially the publications of the World Bank, e.g. 55. 
influence on the whole system and its components, that is, a complex concept of wellbalanced measures taking the complementarity of the sub-systems into account. It is true that there is no unequivocal evidence of its implications and consequences as a methodological approach. But, in principle, the concept should be appropriate for achieving simultaneously the basic development goals ${ }^{5}$ in the rural areas in developing countries. Further, the discussion focusses on the aspect of the concept as a methodological approach.

Substantially, the rural development process calls for changes in the following problem areas:

- the economic development of rural sectors including their relations with the national and international economic system;

- social mobilization and development;

- political development;

- changes in the system of values, norms, and attitudes.

These changes, influenced by a well-balanced system of measures $(26, \mathrm{pp} .142 \mathrm{f}$.), should be effected while taking the available resources, the existing social and economic systems, and the historical experiences of the people concerned into consideration. Therefore, these are no universal ways and means of achieving the goals. In the process of change, the following factors are especially important:

- Structural changes in the economic system, especially regarding the access to productive resources and to an increase in productivity.

- Organization of adjusted allocation systems.

- Establishment of a system of political cooperation.

- Creation of an adjusted settlement structure including the necessary infrastructural institutions.

- Creation of employment opportunities in the rural areas whereby technological problems are of importance.

- Establishment of economic, social, political, educational, and other institutions of rural development as change agents.

From the multiple spheres in which changes are necessary, relevant components which are essential under the strategical aspect should be selected for operationalization. The following are considered to be of a crucial importance for the IRD concept under the strategical aspect:

- decision patterns for investments in rural areas;

5 Basic development goals are:

- economic growth

- employment

- equity

- participation

independence

- cultural integrity.

Simultaneous efforts should be made in all societies to achieve these goals. Indeed, the priorities will differ in the individual countries (48; 30; pp. $22 \mathrm{ff}$. and the literature quoted there). 
- settlement structures; and

- the economic, social, and political institutions, here, especially in connection with the first two components, their spatial distribution.

It is presumed that the objectives in the rural development process which, among others, means integrating marginal population groups, mobilizing them and allowing them to participate, can be achieved more realistically in all fields under the conditions prevailing in the developing countries only with the help of a decentralized approach. ${ }^{6}$ The multiple decisions which are necessary are likely to make an excessive demand on a central decision-making system. Altogether, this means establishing a decentralized decisionmaking structure (26, pp. $146 \mathrm{ff}$.) in all fields ${ }^{7}$ which, consequently, calls for an appropriate spatial structure. However, appropriate models are required for establishing sparial structures and, thus, for locating decision-making institutions in all fields (economic, administrative, political services) on the one hand, and for sectoral investment decisions, on the other hand. Such models could result from the already mentioned combination of the central place theory and the strategy of ibalanced growth.

\section{Concept of a Combined Spatial and Sectoral Strategy for Rural Development}

\subsection{The Principle}

With regard to rural development in the Third World countries, it was considered essential to establish a decentralized decision structure for all spheres of life. This requires the creation of a relevant spatial structure such as the establishment or expansion of an appropriate settlement structure and the communication structure adjusted to it. The settlements are then the locations for handicrafts, industrial enterprises, service institutions, administration, and other institutions. The medium and subcentres distributed in the rural areas then have the important function of stimulating development. It can be ascertained that the impulses of decentralized industry and service-centres in the rural areas alone are not strong enough to initiate or speed up development since the economic and social structures in the rural areas and the distribution of power within the rural regions and between the rural areas and the urban centres of ten restrain or prevent a transformation process leading to development. This is why it is also indispensable to establish specific service institutions of rural development (31). Such change agencies

6 Indeed, adhering to a decentralized approach demands a deliberate political decision and its enforcement by a powerful government. For a central bureaucracy, decentralization means a loss of power and is, therefore, difficult to enforce since it is against their interests. On the other hand, decentralization encourages local autonomy and efforts to achieve autarky. The political realization of prescriptions for a decentralized rural development has not yet been solved in the concepts.

7 Thus, the consequences and implications of unavoidable wrong decisions are mitigated. There are indications that the economies, which decentralize the economic decision process, achieved, at long term, the highest growth rates. Cf., for example, the People's Republic of China, Taiwan, and Korea (cf. the World Bank survey in 36, p. 13). 
have a direct influence on the factors impeding development in the rural hinterland. On the other hand, the locations of institutions in rural areas are also the nodes for enterprises of the secondary sector. However, even the decentralized industrialization of the rural areas cannot remove the above-mentioned structural restraints but only reduce their influence because of the vicinity of these small and medium development centres to the rural hinterland. The improvement of physical, institutional, and personal infrastructure is another important factor in that respect.

A basic pattern for a spatial decision structure or rather a model for explaining the organization of space is Christaller's (Ref. 9) central place theory and its elaboration by other authors (see, e. g. 4). The theoretical pattern explains the spatial distribution, location, and size of the settlements, the hierarchical interrelations and their functions. The most appropriate organization for the development process is considered to be the spatial structure determined in accordance with economic principles (market forces). ${ }^{8}$ In most of the developing countries, in the course of the historical process, the choice of locations was very often determined by other principles $^{9}$ which created a spatial structure impeding the present development. The central place theory is also a location theory of the tertiary sector (6, pp. $110 \mathrm{ff}$.) although its scope reaches far beyond this sector, since the locations are also those of enterprises of the secondary sector. This approach could also be used as a decision aid for the spatial allocation of investments in other sectors. An appropriate allocation pattern for decisions regarding decentralized sectoral investments in the rural development process is Nurkse's strategy of salanced growth (39). According to this approach, one of the causes of the slight propensity to invest is the limited size of markets due to the lack of purchasing power. This is why, for tactical reasons, a strategy for the balance of supply and demand is pursued in the consumer goods sector with a view to improving the incentives to invest. Thereby, the investments create their own market (Say's theorem). Therefore, investments should be made in the sectors which satisfy the potential demand (of masses). The heterogeneity of demand determines the necessity of investing in numerous economic sectors $(39$, p. 12). These multiple sectors, in turn, call for a tendency to reduce the size of operational units. The benefits of the simultaneous growth of the consumer goods industry can only be realized through the market because of the external effects.

Decentralized investments in the sector of consumer goods and the directly preceding sector of investment goods as foreseen (see above) in the rbalanced growth investment strategy imply the exercise of an active influence on the structures, norms, and values of

8 In addition to the market principle, Christaller considered that transport and administrative principles organize space. Lösch (Ref. 29) and Johnson (Ref. 20) found that these principles are special cases out of majority of common reasons determining space. In reality, several of these principles produce an effect. Thereby, specific ones were determining the spatial organization in the historical context.

9 ". . . less developed countries (or areas) landscapes have been inadequately influenced by market forces and considerably more affected by military, sacerdotal, juridical, or administrative forces." $(20$, p. 3$)$. "The obvious consequence has been the development of structurally distorted and . . stagnating landscape ..." (21, p. 7). 
the traditional societies in the rural areas. This influence reaches beyond the purely economic creation of incentives by giving to the environment impulses for a decentralized development which effect a change in the behavioural patterns of individuals. It has already been mentioned that mechanisms such as service institutions are necessary for realizing these impacts. In addition, service institutions assume the functions of providing services and utilities of a purely economic nature, especially for agriculture and handicrafts, and should, therefore, be considered directly as instruments of the economic approach in the strategy of balanced growth'. Even in the case of such a decentralized approach, the distribution of resources is unequal, since technical units cannot be divided arbitrarily. Goods, advices, and other stimulating impulses supplied by the service institutions must, therefore, be concentrated, however, only to such an extent that the broad mass of the population is given the possibility of participating.

The combination of the strategy of balanced growth and of the central place theory then yields an integrated pattern of sectoral and spatial investment decisions. With regard to the spatial allocation for investments, it would be expedient to retain the hierarchical principle of distributing and organizing the settlements, as mentioned in the central place patterns. Although the hierarchical system, according to the central place theory, was developed for the tertiary sector only, with regard to the efforts towards industrialization, it offers a spatial approach for allocating funds. The tertiary sector exercises a decisive influence on the locational distribution of the other sectors and vice versa. This means that places having central functions are appropriate because of the advantages resulting from the agglomeration which this location offers as well as because of the concentration of demand (at least potential demand due to the concentration of the population). Industrial locations are likely to (or at least will tend to) assume tertiary functions as well in the course of time (6, pp. $110 \mathrm{f}$.).

In the strategy of sectoral investment, the basic principle of allocation is considered to be the structure and volume of demand for the appropriate products. In actual cases, however, demand can still be too insignificant (low population density and/or low purchasing power) despite the small size of the operational units. An additional criterion for investment decisions is the utilization of existing resources in the regions concerned. The processing of agricultural products for the local requirements as well as for satisfying demand at the national level and even on the world market can be mentioned as an example. The investment pattern of balanced growth, which is based on potential demand, should therefore be complemented by an approach based on the resource availability, especially for creating purchasing power with a view to satisfying material basic needs.

\subsection{Some Empirical Findings}

On the basis of the central place theory, dynamic concepts for a spatial reorganization were implemented in a few countries in combination with an integrated rural development approach. The aim was to supply the most diverse services in the rural areas in 
order to meet the minimum requirements. Adequate structures were established in several countries by creating rural growth centres within the framework of rural development planning. Thereby, decentralized nuclei of industrial development are located in central places classified in a hierarchical order. The smallest decentralized growth centres offer locations for industrial and service centres of a low level; that is, the economic units should be small and the service centres carry out activities which can also be offered in small units and for which there is a frequent demand. On a higher hierarchical level larger units carry out activities requiring a greater degree of concentration, etc. In the two countries, India and Pakistan, while taking into account the political and administrative changes, an attempt is being made to implement, with the help of models of location planning, programmes for an agricultural, industrial, and institutional development within the framework of an integrated rural development. The various activities for developing the rural areas, including the structural changes necessary to that end, are included and coordinated in the decentralized development programmes of the Integrated Area Development Program ‘ in India (see 49; 1; 2; 34, pp. 144 ff.; 35; 37; 53) and of the 'Integrated Rural Development Program' in Pakistan $(12 ; 21 ; 22 ; 41)$ under functional (socioeconomic activities) as well as spatial aspects. Most of the programmes are still in the pilot phase.

Integration implied the recognition that all development activities have a spatial aspect since, in addition to the functional dimension, the location of an activity is also of decisive importance. Since not all development promoting activities can take place or be offered everywhere and to the same extent in every place, it is necessary to distribute them horizontally (under the spatial aspect) as well as vertically (under the functional aspect). Thus, development planning in these two countries follows, in its initial stages, the concept of balanced growth $(49$, p. 2$)$. But only when the balanced growth development strategy (sectoral distribution of investments) is rationally combined with the central place patterns (concept of regional distribution) does an overall concept emerge. Promoting industry in addition to developing the rural areas without integration, as is pursued in India with the concepts of centralized establishment of capital goods industries and of community development programmes, turned out to be a failure $(49$, p. 1$)$ because the spatial components were ignored in the community development programmes. There is no doubt that this failure sped up the search for new concepts for developing the rural areas and contributed to the integrated rural development programmes. According to the proportion to which development activities or rather service functions for the rural areas are spatially distributed, the immediate result is a hierarchy of rural centres as locations for handicrafts and industries or as suppliers of these functions for the surrounding area. The hierarchy of the places is determined in the planning concepts of the two countries by the degree of centrality of services and by their suitability as location for settling decentralized industries. In order to use the development impulses of the industry, the combination of the concept of decentralized industrialization and the location model of the tertiary sector, the central place theory, seems to be a promising alternative for development planning. 
The two above-mentioned countries try to integrate the locations of industry and service functions on different hierarchical levels, the so-called rural growth centres, into the development planning for rural areas.

In Pakistan, for example, according to available reports (12), the lowest level of rural growth centres is the 'Markaz' in which, in addition to service activities for the rural hinterland, small-scale industries are also located (21, p. 2). Each Markaz serves 60-100 villages covering an area of 300-500 sq. miles (22, p. 5). In the hierarchical system, above the 'Marakaz' are the 'Agrovilles' in which some of the middle-scale industries are located. However, the exact functional levels, the size and distribution of the central places in Pakistan's rural areas are not determined although a few suggestions have been made in that connection (21, pp. $5 \mathrm{f}$. and $26 \mathrm{ff}$; 43$)$.

In Israel, within the framework of the reorganization of the settlement structure, centres of various hierarchical levels were created. The centres which were to supply the surrounding, mostly cooperative production enterprises from various sectors (mostly agriculture) and the people living there with commodities and services (the so-called "Bcentres") are located between the settlements and are usually uninhabited (38).

In Indonesia, within the framework of the 'Area Development Project' (ADP) in West Pasaman/Sumatra $(24 ; 25 ; 17)$, the organization of the spatial structure according to the central place theory is planned on the basis of the prevailing settlement structure. This also includes the improvement of communications. Two centres were selected in that region ('bi-polar integrated development (). These should supply high quality services. At a lower level, sub-centres and secondary sub-centres for supplying 'normalı services or rather services orientated towards meeting the basic requirements ('decentralized concentration') are foreseen. It is expected that the development of transportation will expand the trading areas of central places and, at the same time, provide incentives for increasing the productivity.

The expansion of the central places by providing them with economic, social, educational, and cultural service institutions and by developing a communication system results in a considerable resource transfer into the region of Pasaman. According to the obtained information, priority is no longer accorded to this distribution approach. The economic sectors - according to the potential - should rather be identified, mobilized, and promoted (approach based on resources). This means especially the development of agricultural production and fisheries as well as handicrafts and small industries which are still at the initial stage. This would mean a further step towards the goal of an autonomous (and self-financed) development.

In other developing countries ${ }^{10}$ as well, approaches can be perceived whose objective is to supply services and important commodities to the population by creating rural centres partly within the framework of strategies aiming at satisfying the basic needs.

A factor which is common to all (!) approaches is that they, indeed, involve the func-

10 Thus, for example, for Tanzania (42, pp. 169 ff.), Kenya (3), Portugal (32, pp. 59 ff.), Malawi (10, p. 22).

The organization of Farmers' Association in Malaysia and Taiwan also involve such aspects. 
tional aspects and the spatial distribution thereof, but leave out of consideration the decision criteria for the sectoral and functional distribution (if at all, then only as a negligible variable). That is, they focus their attention on the spatial components of structures and processes. Therefore, these approaches lack an integrated sectoral and spatial pattern for decisions regarding the activities and, thus, for investments. This is intended to be a first attempt to integrate the two fields.

\subsection{Elements and Limitations of the Combined Approach}

The combination of the balanced growth strategy and the paradigma of central places basically results in an integrated sectoral and spatial decision pattern for investments or rather for central elements of development activities. To that end, however, further definite components are required. Therefore, in the following, relevant elements from the two approaches as well as the limitations of the combined approach will be discussed:

\section{(1) Decision-making agents}

One of the important questions when planning development is that of the competence of the different institutions or persons with regard to decision-making. Selecting and fixing the location of institutions of the tertiary sector, as outlined in the basic model in the central place theory, means, for developing countries, that the decisions ought to be made mostly by government institutions. ${ }^{11}$ The service structure (service institutions of rural development) which is necessary for development will be planned and implemented mostly by government offices. Guidance in the planning process as to the volume of service institutions can consist in ascertaining the basic needs, on the one hand, and the demands of the production sectors regarding an effective development (e. g., in agriculture; extension, credit, marketing, etc.). Thereby, the places must be selected and then, according to the hierarchical system, allotted various functions when they become the locations of service institutions. The question as to who makes the decisions regarding the location of trade supply institutions cannot, in contrast, be answered in definite terms. This is likely to depend, to a large extent, upon the social and economic order. Regarding investment decisions in the production sector (especially handicrafts and appropriate industry), government often plays a dominant role, although there are various alternatives. The location of operational units is largely predetermined, with some exceptions, when it is selected within the framework of the central place patterns. With regard to the distribution of the investment volume among the economic sectors (distribution criteria, see below), the opinion is commonly held that the government

11 Since in most of the developing countries, the tendency is rather to centralize and concentrate (in this connection, see 7, pp. $22 \mathrm{ff}$.) that is, no hierarchical network of central places 'spontaneously' emerges, it is necessary that government institutions exercise an active influence on the organization and expansion of such networks. 
itself should make these decisions by investing. ${ }^{12}$ Accordingly, only government institutions are in a position, since they command the overall situation, to make the "right" investment decisions according to a total plan. In contrast, Nurske and a few other authors argue that the incentives of a balanced growth are not necessary for the government to decide upon the distribution of investments. The balanced growth concept as a model for the mutual, simultaneous inducement of investment decisions is precisely an approach promoting private investments in the right' sector (40, p. 249). In practice, it is necessary, for numerous reasons, that the government, by means of an indicative plan, and specific initial investments into important strategical sectors (such as, for example, the establishment of a service structure and the location decisions necessary to that end but also in the infrastructural sector and, eventually, in the production sector as well) determine the direction which will then serve as a guideline for private investment activities. In principle, however, balanced growth is an approach aiming at creating incentives for the private investment sector. At any rate, private investors base their decisions on the private marginal productivity which is not identical with the social marginal productivity due to external effects. For that reason, it is necessary (see 14, pp. 267 f.) that the government influence investments so that the decisions of the private economy guarantee as closely as possible the welfare of the whole society.

Due to the necessarily great influence exercised by the government ('top-down' planning), the power of the bureaucracy is likely to increase in that concept. This is a perceptible phenomenon in most of the developing countries. It can therefore be assumed that the administration, for the purpose of increasing its power potential, is favourable to such an approach.

In reality, the necessary decisions go far beyond the capacity and competence of the central government $(14$, p. $280 ; 16$, p. $249 \mathrm{ff}$.). However, because of the necessity of creating decentralized structures (see above), there is an opposite tendency to decrease the concentration of power of the central administration. Necessary decisions at the local or regional level are then made by the appropriate institutions (governmental, semi-governmental, and private). Thus, the influence of central bureaucracies is reduced. This is why it can be assumed that these would rather oppose a decentralized approach.

12 Especially Rosenstein-Rodan (44, p. 204; 45, pp. 393 ff.) in his 'big push strategy akin to balanced growth, assumes that a large number of minimum investments is necessary for initiating economic development. Thereby, these investments can only be effected with a central planning (in this connection and for assessing the necessity of government planning, see 14, pp. 276 f.; 15, pp. 534 ff.; 50, p. 24 and the literature quoted in each of these publications). 


\section{(2) Decision Basis.}

The basis of investment decisions for several sectors is the development of demand for the individual products. On the basis of the existing demand adjusted to production, ${ }^{13}$ the income elasticities of demand serve as a guideline for production growth and thus for the necessary investments. In reality, this decision rule for the sectoral distribution of investments should not be interpreted too closely. Income elasticities are more likely to show a trend at long term (14, pp. 262 f.; 15, pp. 562 f.) since price relations, too, will not remain constant. Therefore, it is neither necessary, nor purposeful to unconditionally produce every commodity for which there is a demand (for the degree of diversification in production, see below) (40, p. 252).

If the income elasticities of demand should serve as a rough guideline for investments, the question should be posed how realistic this approach is with regard to the rural areas in developing countries (and not there only). There, a large part of the population live on a physical subsistence minimum. They have no productive employment opportunities and, thus, no purchasing power which could exercise an influence on demand in the terms mentioned above. Therefore, other criteria should be considered as a decision guide. At this stage of development, adjusting the production of vital commodities to the basic needs could be an important criterion. ${ }^{14}$ However, ascertaining the basic needs and the investments which are necessary if those are to be satisfied can mostly be done by public institutions alone since private investors will not invest into sectors where the social marginal productivity (here, it should realistically be assumed that this is very high when satisfying the basic needs) very strongly deviates from the private one.

\section{(3) Diversification of Production}

In fact, it is realistic to expand the size of markets through balanced growth only by expanding the domestic market. The export market for most of the countries is limited by the multiple import restrictions of the industrial countries. ${ }^{15}$ But, on the other hand, precisely the concentration on the domestic market allows a strategy utilizing appropriate technologies which are capital-saving and create employment opportunities and only allow a decentralized development approach. How far should a diversification of production extend now? Nurske argues $(40$, p. $252 ; 15$, p. 534) that not every commodity for which there is a demand ought to be produced. Thus, too many small units would be created whose market is not large enough. It is much more a question of investing into

13 In developing countries, there are at present marked imbalances in the variety of products as compared with the structure of needs and demand which should primarily be adjusted. But, consequently, this means an imbalanced growth to equilibrate supply and demand.

14 The tremendous problems of delimiting basic needs and of implementing this concept can only be pointed out here (see the relevant literature).

15 See the discussions in 15, pp. $529 \mathrm{ff}$. Among these, there are, of course, numerous exceptions for specific products. 
the important sectors of the consumer goods industry. Thereby, the degree of diversification depends upon several factors such as the adequate economic size of enterprises, their position in foreign trade, non-economic factors, utilized technologies which, among others, are, on the whole, again a function of the stage of development.

An extensive decentralization utilizing appropriate technological methods of production allows the organization of several small individual enterprises in the central places of different hierarchical levels. Thus, the specific local and regional needs of the population can much earlier be satisfied than in the case of a centralized development concept. On the other hand, creating a sufficiently large number of employment opportunities secures a broad dispersion of purchasing power which then influences demand. Thus, the creation of employment opportunities (and therefore of effective demand) is inherent in the concept of balanced growth.

\section{(4) Sectors of Investment}

Investments into the sector of consumer goods in the balanced growth strategy conceived by Nurske also implies expressis verbis the development of agricultural production at least insofar as the production of foodstuffs is concerned (40, pp. $251 \mathrm{f}$.). Since the expenditure for foodstuffs at a low level of development takes up a considerable share of income, it is of the utmost importance to include the development of agriculture into this strategy. With a view to satisfying the non-agricultural demand for foodstuffs (and raw materials as well), agricultural production must exceed subsistence requirements which, in turn, determine through the purchasing power the demand of the agricultural sector for industrial products and, indirectly, the volume of employment in the non-agricultural sector $(52$, p. 33$)$. The above-mentioned interrelations are modified by the production of agricultural commodities for export and/or by the import of foodstuffs.

Increased demand for foodstuffs as a result of higher total income can, in turn, only be satisfied by investments and an increased productivity in the agricultural sector since investments in other consumer goods industries draws labour away from agriculture. Indeed, the growth rates of the different sectors depend upon each other but they are not equal. According to the specific income elasticity of demand, the growth rate of the individual branches differs and changes constantly according to the alternations in demand.

The development of small-scale industries is of considerable importance in the balanced growth strategy since these small enterprises can cope more rapidly and easily with the deficiencies of underdevelopment and can better react to changes in demand regarding a large number of products $(52$, pp. $34 \mathrm{f}$.) and thus have a relatively high production elasticity.

A few additional reasons, especially of economic nature, favour the decentralized industrialization. The small operational units have only a limited market. In the initial phase of investment, they find an insignificant purchasing power and, thus, demand. Moreover, production in small units requires an insignificant share of fixed costs. The enterprises 
are run mainly with a high share of variable costs which, in turn, increases their degree of adaptability (5, pp. $287 ; 54$, pp. 155 f.). This tendency is further supported by the utilization of appropriate technologies which means a low level of technology. These, in turn, reduce the capital requirements for every place of employment. For such investments, forms of capital can be used which are more easily accessible to individuals in the rural areas, that is, which require less 'modern' capital in the form of imported investment goods. For such investment decisions, it is usually not necessary to train entrepreneurs in the modern sense.

On the other hand, in the case of a decentralized industrialization, the problems caused by a deficient communication infrastructure hardly impede distribution. The enterprises are localized in the vicinity of places where underemployment is seasonal and thus reduce the costs of migration. Moreover, it is easier to organize and manage small enterprises, and the consequences of initial wrong decisions are limited. The decentralized location of industrial enterprises in rural areas facilitates the contact possibilities as well as the possibilities of exercising influence with a view to developing the hinterland. Thereby, however, the restrictions outlined in Chapter 3.1 regarding the transfer mechanisms should be taken into consideration.

Nurske presumes the availability of a sufficient amount of capital in the developing countries $(39$, pp. $30 \mathrm{f}$.). But precisely in the rural areas, there is a lack of capital resources which can have various causes. With reference to the investment strategy, this deficiency can, at least, be mitigated by using adapted, in this case, lower technological standards.

\section{(5) Regional Diversification}

According to the approach of balanced growth, the advantages of this strategy can only be realized through the market (internal and external savings). Thereby, until now, the discussion has taken place at the national level and included partially the world market. A concept for decentralizing decision structures means, consequently, because of the insignificant capital requirements, that the infrastructure (especially communication infrastructure) should not be oriented towards the national centres but towards a lower level (e. g., regions). Thus, the market in the balanced growth strategy would comprise the regions (of varying sizes in the individual countries) and so-called regional microeconomic cycles would be created which could then be integrated partially into the national and, eventually, in the cycle of world economy. Thus, the effects of balanced growth on the market could be realized. ${ }^{16}$ The problem of reducing the size of the market could be solved, here, by multiple small operational units. However, the amount of internal savings of those units, because of the low levels of technology, would not be

16 Reducing the size of the market to the village level or further to the household level (meeting the subsistence requirements) would not cause balanced growth to produce any effect and will not be dealt with further although this, could, indeed, be relevant for reducing risks. 
considerably large. Growing tendencies of regional autarky or autonomy due to such a decentralization will surely be rejected by the central governments of many developing countries for reasons of national policy. Since a loss of influence and power of the central administrative institutions and of politicians is also connected with decentralization, the political implementation of the approach actually poses one of the most difficult problems.

\section{(6) A Few Counter-arguments}

The development strategy of balanced growth has been criticized from many quarters, however, without plausible arguments against this concept being put forward, especially in comparison with other approaches $(52, \mathrm{pp} .37 \mathrm{ff}$.). In addition, two counter-arguments which refer directly to the present contribution will be dealt with:

- The simultaneous development of the whole consumer goods sector leads to an uneconomical dispersion of already scarce resources. Especially the decentralized establishment of several small capital-saving but labour-intensive production units do not allow that, on the one hand, the advantages of external savings or of the localization and urbanization economies' $(18$, pp. 172; 19, p. 433) be made use of and, on the other hand, the advantages of internal saving (economies of scale) would be lost. The integrated development of a country, precisely the decentralized location of industry according to the models of the central place theory offers a series of advantages which, at least, compensate for the disadvantages mentioned above. At the beginning of development, it is not intended either to introduce the highest technological levels of production which would therefore require a very large amount of capital so that the advantages of agglomeration resulting from centralization would not be excessive. On the other hand, consumer goods and processing industries have an easier access to the lower levels of technology in small scale enterprises.

- For stimulating a process of growth, minimum impulses are necessary which, on the whole, require a large amount of scarce production factors.

Precisely decentralized industrialization, with its multiple possibilities of influencing and of giving impulses to an overall economic development, offers advantages which do not allow an excessive increase in the requirements for production factors and, here especially, capital. If appropriate intermediate technologies, which are optimally localized in small operational units, are used, there will be a reduction in capital requirements. However, for development, the scarcely available human capital actually means a bottleneck which does not specifically emerge in the strategy of balanced growth but is a general phenomenon and characterizes the low level of economic development. 


\section{(7) Locations and Functions of Rural Centres}

The application of the two development strategies in a combined approach calls for the active expansion or establishment of central places of varying importance as development centres in the rural areas. Until now, in many developing regions, no balanced growth had been possible, among other reasons, because no centres were available for locating service institutions, ${ }^{17}$ handicrafts, etc. The settlements of varying size which should be established then serve as location for handicrafts and industrial enterprises as well as centres supplying commodities and services to the rural population and as the seat of political and administrative institutions and organizations.

The distribution of decentralized locations for enterprises of the secondary sector in the rural areas has the decisive advantage that the hitherto underemployed or unemployed labourers from agriculture find work more easily and this in the vicinity of their places of residence. They have the possibility of acquiring purchasing power and of coming forward as buyers of the commodities produced in this sector and especially of foodstuffs. The supply of industrial consumer goods stimulates, in turn, agriculture to extend its supplies on the market. Since a spatial homogeneous distribution of industrial production is hardly possible because of the high costs of production and distribution, decentralized industrialization in rural central places is the opportunity which offers itself (33, pp. $165 \mathrm{ff}$.). The industrial locations are themselves a criterion for the hierarchical position of a central place, as a location for service institutions is not necessarily also a location for industry, since optimal spatial distributions for production and supply economy do not tally. Due to a series of advantages (e. g., urbanization effects), there will, in practice, still be a combination $(51$, p. 165$)$. If the appropriate technological standards are taken into account, the locations emerge for the individual industrial enterprises and handicrafts subject to the advantages of internal and external savings in central places of varying hierarchical order and, thus, size. Small handicrafts and repair workshops which can be decentralized find a location even in the rural sub-centres whereas industrial enterprises and also handicrafts should mostly be established in rural centres of a higher order up to the major urban centres. The lower limit of decentralization is determined by the minimum size of the smallest operation unit in the secondary sector (or rather the minimum supply in the tertiary sector) which, among others, is a function of the technological standard.

When supplying the centres and their hinterland with central goods and services, there are, as classically indicated in the central place theory, also hierarchical levels for locating institutions in accordance with the degree of the centrality of the functions assumed by these locations which, in turn, determine the position of the places in the system. With regard to the economic development of agriculture, for example, branches of banks and loan institutions of varying size and warehouses for supplying inputs to

17 See also the arguments put forward by Friedmann (11, pp. $14 \mathrm{ff}$.). 
agriculture find their location in the rural centres. Further, central places must assume an important function as marketing centres for agricultural products and consumer goods. Within the framework of a rural development strategy aiming at satisfying the basic needs, the availability of and access to the economic, social, and educational service institutions at the lowest hierarchical level of the settlement structure (small rural centres, villages) are of crucial importance for meeting the demand and needs of the mass of the rural population (32, pp. $59 \mathrm{ff}$.). Again, these institutions are closey linked with the necessity of creating, at a decentralized level, employment opportunities in the rural areas and thus with the necessity and possibility of increasing productivity and income.

As in most of the countries until now, according to the pattern outlined above, there is also a hierarchical differentiation in the political and administrative organizations. At the lowest level of regional administration, direct, institutionalized mechanisms for coordination with other development institutions such as, for example, rural development societies, service institutions, parties, associations, and self-help groups, should be available for democratizing decision-making and decision-finding at this level and for adjusting all activities. In this context, however, administrative organization is only of secondary importance.

If the rural central places are examined within the hierarchy with regard to their functions, the following classification roughly emerges (cf. the diagram):

- Small rural centre: In the rural areas, this centre is the lowest level in the elaborated system of development centres. Here, artisans and, eventually, small-scale industries find their location. The size of the individual enterprises ought to be very small proportionately to the limited market. With regard to the supply of central goods and services, those offered are the ones for which there is a frequent demand, on the one hand, and which can be offered even in small enterprises, on the other hand. Naturally, in the surroundings and hinterland covered by these centres, there are several places and hamlets which are not organized as centres.

- Medium rural centre (rural central places): Several small rural centres are subordinated to a medium rural centre. These centres offer a location to handicrafts and even to processing industries which make the most of the advantages of an agglomeration. In the service sector, the medium rural centre is the location for commodities and services of a higher order such as, for example, major branches of an investment bank for agriculture and industry. Medium rural centres accommodate central administrative units for the rural areas.

The important question for development planning regarding an appropriate spatial structure is that of the criteria for selecting places in the rural areas as future central places of varying hierarchical levels and their equipment with the functions discussed above. Among others, it is precisely a characteristic of underdevelopment that no appropriate spatial structure for development exists or rather that this has been determined in the past by other factors which now impede development (see $20 ; 21$ ). But even the 
availability of appropriate structures always shows ex-post situations only ${ }^{18}$ and these do not always allow statements on the future structural developments. In any case, here, criteria should be involved which can provide information on the eventual future development potential and possibilities. ${ }^{19}$ But even in industrial countries, this still involves considerable problems of statistical as well as theoretical and methodological nature.

\section{Allocation of Central Functions to Locations (Schema) $)^{1}$}

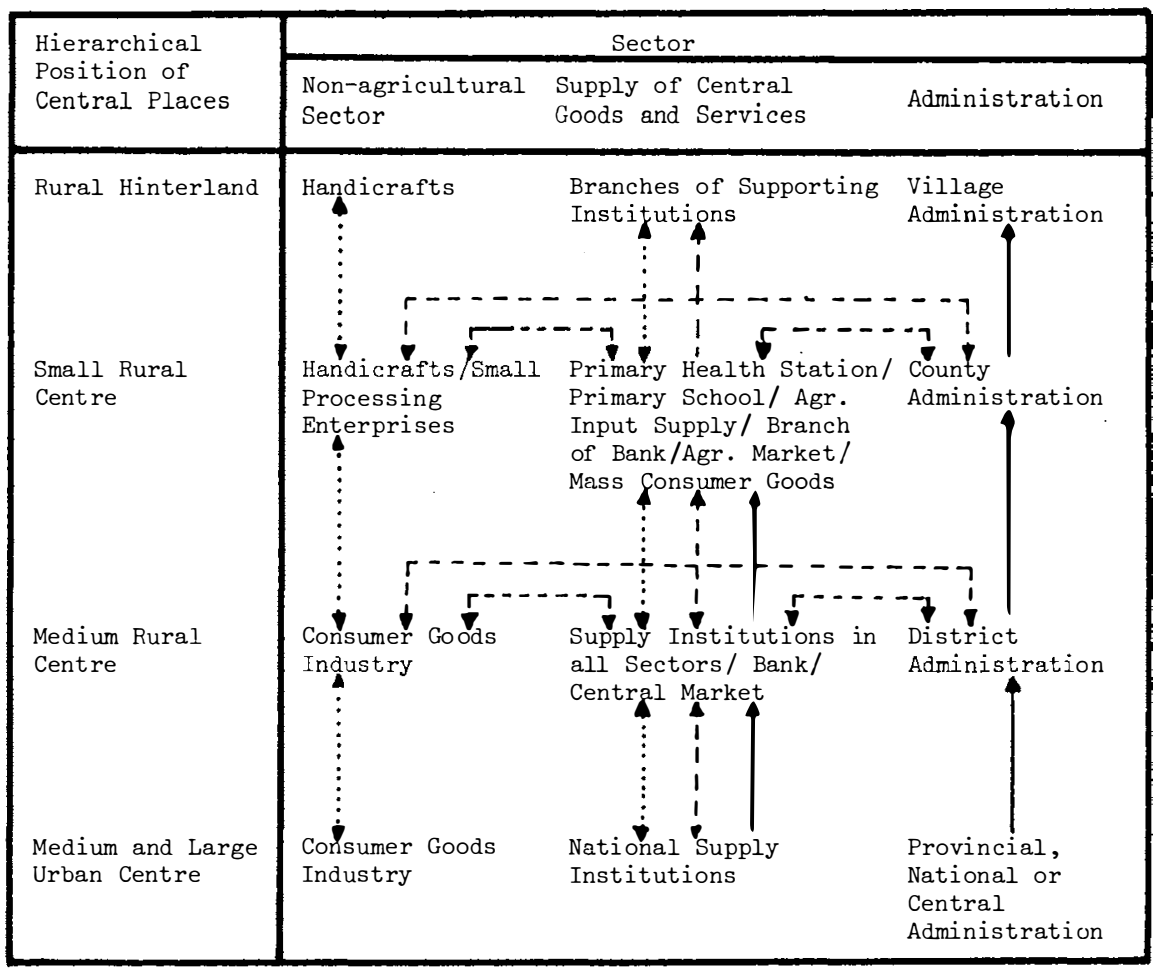

1) In every case, only examples for a representative description were selected.

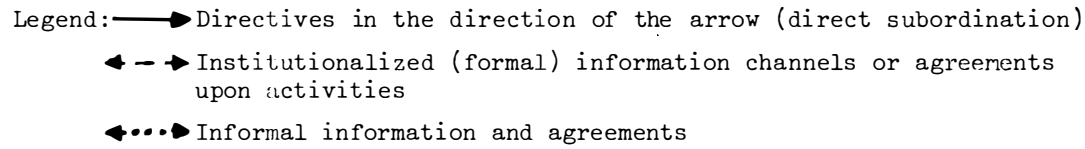

Source: 31, p. 53.

18 This was (is), for example, also a crucial problem when selecting central places in the regional policy in the Fed. Rep. of Germany. There, with the help of various methods for determining centrality, assumptions were made which infer further developments.

19 As substitute indicators for the development capacity of places in an analysis on Lower Saxony in the F.R.G., the economic capacity and the favourable location were included in addition to the centrality of a place (see 13, pp. 74 ff.). 
In view of such problems which affect planning in developing countries, it is probably legitimate to decide upon the selection and distribution of central places, at first normatively, by taking the above-mentioned theoretical findings as a basis and then letting the government institutions assign the necessary functions to these places. Naturally, the settlement structure, the communication infrastructure, etc. hitherto should be included into these mainly political decisions. However, the necessity of equipping the rural areas at least with vital services is likely to be an important guideline just as their suitability for locating industrial enterprises and handicrafts which can be decentralized so that such spatial structures can be financed by these economic activities. ${ }^{20}$

\section{Summary}

Only comprehensive approaches provide an appropriate framework for assessment and action with a view to influencing the development process. However, because of their complexity, such approaches cannot be operationalized forthwith in terms of development policy measures. An attempt has been made to operationalize the concept of 'Integrated Rural Development ' by combining the central place theory and the investment strategy of 'balanced growth in decision patterns concerning the spatial, temporal, and sectoral aspects which are considered to be important for the strategy. Conclusions regarding an actual sequence of investments under various conditions, on the one hand, and their spatial distribution, on the other hand, can be drawn from the combined approach by establishing an appropriate settlement structure. In the present contribution, the problems which the operationalization of the combined approach involves and its limitations are discussed in detail.

20 Several other fields of development policy (e.g., agricultural price policy, taxation, structural chances, social and income policy, institutional frame) have not been discussed here due to limited space.

\section{References}

1. Banerji, S. and Fisher, H. B.: Hierarchical Location Analysis for Integrated Area Planning: Experiences of the Pilot Research Project in Growth Centres, India. (The 1973 Regional Science Congress in Vienna), 1973 (mimeo).

2. Banerji, S., Fisher, H. B., Kumar, T. M. V., Saint, N. S.: Micro Regional Planning for Rural India: Experiences of the Pilot Research Project in Growth Centres. (Submitted for Presentation at Confer-In 73), The Ford Foundation, New Delhi (mimeo).

3. Belshaw, D. G. R., Bjørlo, T.J. and Shah, M. M.: A Hierarchical Systems Formulation of the Rural Development Process in Developing Countries. (Discussion Paper No. 166, Institute for Development Studies, University of Nairobi), Nairobi 1973.

4. Berry, B. J. L. and Pred, A.: Central Place Studies. A Bibliography of Theory and Applications. (Regional Science Research Institute, Bibliography Series No. 1), Philadelphia, Penn., 1961.

5. Besters, H.: Theorien der wirtschaftlichen Entwicklung. In: Besters, H. und Boesch, E. E. (Hrsg.): Entwicklungspolitik: Handbuch und Lexikon. Stuttgart, Berlin und Mainz 1966, pp. 244-304. 
6. Böventer, E. v.: Die Struktur der Landschaft. Versuch einer Synthese und Weiterentwicklung der Modelle J. H. von Thünens, W. Christallers und A. Löschs. In: Optimales Wachstum und Optimale Standortverteilung. (Schriften des Vereins für Socialpolitik, N. F., Bd. 27, hrsg. von E. Schneider) Berlin 1962, pp. 77-133.

7. Boguslawski, M. v.: Regionalplanung und ländliche Entwicklung. Theoretische Grundlagen und praktische Anwendbarkeit in Entwicklungsländern. (Schriften des Zentrums für regionale Entwicklungsforschung der Universität Gießen, Bd. 13), Saarbrücken, Fort Lauderdale 1980.

8. Brandt, H.: Zur Planung landwirtschaftlicher Projekte. (DIE), Berlin 1977.

9. Christaller, $W$.: Die zentralen Orte in Süddeutschland. Eine ökonomisch-geographische Untersuchung über die Gesetzmäßigkeit der Verbreitung und Entwicklung der Siedlungen mit städtischen Funktionen. 2. unveränd. Aufl., Darmstadt 1968.

10. Entwicklung und Zusammenarbeit, (hrsg. von der DSE), 6/1981, p. 22.

11. Friedmann, J.: Regional Development Policy: A Case Study of Venezuela. Cambridge, Mass. and London 1966.

12. Haider, A.S and Khan, D. A.: Planning for Rural Development: Reflections on Integrated Rural Development Program. (A Paper Presented at the Cento Seminar on Agricultural Planning from Nov. 27 - Dec. 4, 1972 in Islamabad, Pakistan), Islamabad 1972.

13. Hellberg, $H .:$ Zentrale Orte als Entwicklungsschwerpunkte in ländlichen Gebieten. Kriterien zur Beurteilung ihrer Förderwürdigkeit. (Beiträge zur Stadt- und Regionalforschung. Hrsg. im Auftrage des Wissenschaftsrates der Gesellschaft für Wohnungs- und Siedlungswesen (GEWOS e. V.) Hamburg, von H. Jürgensen, H. 4), Göttingen 1972.

14. Hemmer, H.-R.: Wirtschaftsprobleme der Entwicklungsländer. Eine Einführung. (Vahlens Handbücher der Wirtschafts- und Sozialwissenschaften), München 1978.

15. Hoffmann, L.: Entwicklungstheorien des ausgewogenen und unausgewogenen Wachstums: Eine Gegenüberstellung. Zeitschrift für die gesamte Staatswissenschaft, Bd. 121 (1965), pp. 523-574.

16. Ilchman, W. F. and Bhargava, R. C., Balanced Thought and Economic Growth. In: Riggs, F. W. (ed.), Frontiers of Development Administration, (Comparative Administration Group Series), Durham, $N$. C. 1970 , pp. $247-273$.

17. Integrierte ländliche Regionalplanung in West-Pasaman/West Sumatra. Ergebnisse einer indonesischdeutschen Projektfindungsmission. Studie im Auftrage der GTZ. Eschborn 1979.

18. Isard, $W$.: Location and Space-Economy. A General Theory Relating to Industrial Location, Market Areas, Land Use, Trade, and Urban Structure. (The Regional Science Studies Series, ed. by W. Isard, No. 1), Cambridge, Mass. and London 1956.

19. Isard, W. et al.: General Theory: Social, Political, Economic, and Regional. With Particular Reference to Decision-Making Analysis, (The Regional Science Studies Series, ed. by W. Isard, No. 8), Cambridge, Mass. and London 1969.

20. Johnson, E. A. J.: The Organization of Space in Developing Countries. Cambridge, Mass., 1970.

21. Khan, D. A.: Central Place Theory a s basis for the spatial reorganization of Pakistan's rural landscape. (Occasional Papers, Materialien zur Reihe 'Sozialökonomische Schriften zur Agrarentwicklung', hrsg. von F. Kuhnen, Bd. 1), Saarbrücken 1975.

22. Khan, D. A., Haider, A.S. and Siddique, M.: Approaches to Rural Development: Reflections on Integration and Techno-Economic Aspects. (A Paper Presented at the International Rural Development Seminar from April 2 - April 5, 1973 at Peshawar), Peshawar 1973.

23. Kötter, H. R.: Some Deliberations on Basic Principles and General Strategy Underlying Integrated Rural Development. Monthly Bulletin of Agricultural Economics and Statistics, Vol. 23, No. 4, (FAO), Rome 1974.

24. Kruse-Rodenacker, A. et al.: Development Plan for West-Pasaman/Sumatra. Berlin 1975.

25. Kruse-Rodenacker, A. et al.: Operational Programmes for West Pasaman/Sumatra. Berlin 1975.

26. Kuhnen, F.: The Concept of Integrated Rural Development. Korean Journal of Agricultural Economics, Vol. 19 (Sept. 1977), pp. 137-147.

27. Kuklinski, $A$. (ed): Growth Poles and Growth Centres in Regional Planning. (United Nations Research Institute for Social Development, Geneva, Regional Planning, Vol. 5), Paris, The Hague 1972.

28. Leupolt, $M .:$ Zum Konzept der integrierten ländlichen Entwicklung. Zeitschrift für Ausländische Landwirtschaft, Jg. 15 (1976), pp. 5-21.

29. Lösch, A.: Die räumliche Ordnung der Wirtschaft. 2. neu durchgearb. Aufl., Jena 1944.

30. Manig, $W .:$ Zur Diskussion einer gesamtgesellschaftlichen Entwicklungstheorie. Quarterly Journal of International Agriculture, Vol. 19 (1980), pp. 18-38.

31. Manig, W., unter Mitarbeit von Prunzel, E.: Räumliche Aspekte ruraler Entwicklung. Das Problem der 
zweckmäß3igen Größe von Aktionsräumen bei ländlichen Förderungsinstitutionen in Entwicklungsländern. (Sozialökonomische Schriften zur Agrarentwicklung, hrsg. von F. Kuhnen, Bd. 44), Saarbrücken und Fort Lauderdale 1982.

32. Maver, J.: Spatial aspects of basic-needs strategy: the distribution of essential services. International Labour Review, Vol. 118 (1979), pp. 59-74.

33. Mever, J. F.: Sozialökonomische Aspekte einer Industrialisierung ländlicher Problemgebiete. Soziologia Ruralis, Vol. XV (1975), pp. 165-172.

34. Misra, R. P.: Growth poles and growth centres in the context of India's urban and regional development problems. In: Kuklinski, $A$. (ed.): 27, pp. 141-168.

35. Misra, R. P., Sundaram, K. V., Prakasa Rao, V. L. S.: Regional Development Planning in India. A New Strategy. New Delhi 1974.

36. Morawetz, D.: Fünfundzwanzig Jahre wirtschaftliche Entwicklung. Finanzierung und Entwicklung (hrsg. vom IMF und IBRD, Washington), Hamburg, Jg. 14 (1977), H. 3, pp. 10-13.

37. National Council of Applied Economic Research (NCAER): Market Towns and Spatial Development. New Delhi 1972.

38. National and University Institute of Agriculture, Rehovot, Settlement Study Centre: Spatial Organization of Rural Development (by R. Weitz) and Development Trends of Spatial Rural Cooperation in Israel (by I. Prion), (Publications on Problems of Regional Development, 3), Rehovot 1968.

39. Nurkse, R.: Problems of Capital Formation in Underdeveloped Countries. Eighth Impression, Oxf ord 1962.

40. Nurkse, R.: The Conflict between "Balanced Growth" and International Specialization. In: Haberler, $G$. and Stern, R. M. (eds.): Equilibrium and Growth in the World Economy. (Harvard Economic Studies, Vol. CXVIII), Cambridge, Mass., 1962, pp. 241-259.

41. Pakistan, Gov. of, FAO, UNDP: Report of the International Seminar on Integrated Rural Development. Lahore, Nov. 3-10, 1973.

42. Pióro, Z.: Growth poles and growth centres theory as applied to settlement development in Tanzania. In: Kuklinski, $A$. (ed.): 27, pp. 169-194.

43. Qadeer, $M$. A.: An Evaluation of the Integrated Rural Development Programme. (The Pakistan Institute of Development Economics, Monograph No. 19), Islamabad 1977.

44. Rosenstein-Rodan, P. N.: Problems of Industrialization of Eastern and South-Eastern Europe. The Economic Journal, Vol. 53 (1943), pp. 202-211.

45. Rosenstein-Rodan, P. N.: The Theory of the "Big Push". In: Meier, G. M.: Leading Issues in Economic Development. Studies in International Poverty. 2. Edition, Oxford 1970, pp. 393-398.

46. Ruthenberg, $H$. .: Is Integrated Rural Development a Suitable Approach to Attack Rural Poverty? Quarterly Journal of International Agriculture, Vol. 20 (1981), pp. (-14.

47. Schönherr, S.: Konzeptionen ländlicher Entwicklungspolitik. Zeitschrift für Ausländische Landwirtschaft, Jg. 18 (1979), pp. 5-18.

48. Seers, $D$.: What are we Trying to Measure? Journal of Development Studies (Special Issue on Development Indicators), Vol. 8 (1971/72), No. 3, pp. 21-36.

49. Sen, L. K. et al.: Planning Rural Growth Centers for Integrated Area Development. A Study in Miryalguda Taluka. (National Institute of Community Development), Hyderabad 1971.

50. El-Shagi, El-Shagi: Die Strategien des "gleichgewichtigen" und "ungleichgewichtigen Wachstums": Alternative Wege oder partielle Ansätze? SSIP Bulletin, Nr. 48 (Winter 1978), pp. 22-33.

51. Spitzer, H.: Regionale Landwirtschaft. Die Entwicklungsaufgaben der "Region" fü r Landwirtschaft und Raumordnung. Hamburg und Berlin 1975.

52. Timmermann, V.: Probleme und Möglichkeiten der Entwicklungsplanung. Die Strategie des balanced growth. (Veröffentlichungen der Wirtschaftshochschule Mannheim, Bd. 17), Stuttgart, Berlin, Köln, Mainz 1967.

53. Wanmali, S.: Regional Planning for Social Facilities. An Examination of Central Place Concepts and Their Application. Á Case Study of Eastern Maharashtra. (National Institute of Community Development), Hyderabad 1970.

54. Wood, C. L.: Industrielle Entwicklungsprogramme und die Rolle regionaler Zentren. In: Entwicklung von unten. Probleme und Stufen des sozialökonomischen Wachstums auf der regionalen Ebene. (Ein Internationales Symposium der Wirtschaftspolitischen Gesellschaft von 1947 vom 26.-30. 7. 1967 in Berlin), Köln und Opladen o. J., pp. 144-156.

55. World Bank: Rural Development. Sector Policy Paper. Washington, D. C., 1975.

56. Wulf, R.: Integrated Rural Development. Entwicklung und Aussichten des Konzepts. (Institut für Agrarpolitik und Marktlehre der Universität Kiel, Diskussionsbeiträge, Nr. 27) Kiel 1977. 


\section{ABSTRACTS}

\section{Towards Operationalizing Complex Development Approaches}

\section{By Winfried Manig}

There is no doubt that the disappointment of expectations placed in development policy during the past decades can, to a large extent, be attributed to the lack of a comprehensive development strategy. A complex concept for developing the rural areas in peripheral countries was then elaborated, resulting in the "Integrated Rural Development Approach" (IRD).

In this concept, rural development is understood as a sub-system of the development of the overall society. With this approach, an attempt is made to describe adequately the interdependent processes of change in all sectors in the rural areas in order to be able to influence them according to the basic objectives. On the one hand, IRD is understood as a goal intended to integrate all individuals into the development process; on the other hand, the approach is also a methodological concept for intervention.

It is precisely the complexity of the approach which also constitutes its weakness. Since the concept, as intended, should cover all the sectors of social change, it is too comprehensive as a practical directive for decision-making and action. Therefore, an operationalization of the approach, calling for a concentration on those activities which have essential strategical functions and in which changes produce goal-orientated effects on other sectors, is required. In this contribution, spatial, temporal and sectoral investment patterns, including settlement structure, are identified as such essential sectors. With a view to obtaining an appropriate concept of activities for all sectors and the levels of activity, die "Strategy of balanced growth" (Nurkse) and the "Central Place Theory" (Christaller) are combined, in their relevant elements, into a strategy. The specific sectors of this strategy are discussed with regard to the structure of decisions, the decisional bases, the diversification of production, investment sectors, regional diversification, and the distribution and function of rural settlements. 